\title{
İthal Ham Petrol Fiyatları ve Döviz Kuru Arasındaki Eşbütünleşme ve Oynaklık Yayılma Etkisinin İncelenmesi: Türkiye Örneği
}

\author{
Examining The Cointegration Relationship and Volatility Spillover Between \\ Imported Crude Oil Prices and Exchange Rate: The Turkish Case
}

Alper YILMAZ1', Hüseyin ALTAY²

\begin{abstract}
ÖZET
Bu çalışmanın amacı Türkiye'de döviz kurundaki hareketlerin ham petrol fiyatlarından kısa ve uzun dönemde nasıl etkilendiğini incelemektir. Bu kapsamda 1985-2015 dönemine ait aylık ham petrol fiyatları ve döviz kuru verileri kullanılmıştır. Çalışmada öncelikle ARDL eşbütünleşme yaklaşımıyla seriler arasındaki uzun ve kısa dönem ilişkiler analiz edilmiş ve seriler arasında eş bütünleşme ilişkisi tespit edilmiştir. İkinci adımdaki eşbütünleşme uzun dönem analizine göre ham petrol fiyatlarının kur oynaklığı üzerindeki etkisi negatif ve istatistiki olarak anlamlı bulunmuştur. Kısa dönem analizinde, hata düzeltme teriminin katsayısı istatistiki açıdan anlamlı ve negatif olduğu görülmüştür. Dolayısıyla değişkenler arasında ortaya çıkan sapmaların uzun dönem denge düzeyine yakınsamakta olduğu söylenebilir. Çalışmada son olarak Varyansta nedensellik testi kullanılarak seriler arasındaki nedensellik ilişkisi incelenmiş ve ham petrol fiyatlarından döviz kurlarına doğru bir oynaklık yayılma etkisinin varlığı tespit edilmiştir.
\end{abstract}

Anahtar Kelimeler: Petrol fiyatları, Döviz kurları, Eşbütünleşme Analizi, Nedensellik Testi

\section{GiRiş}

Genel tanımıyla yabancı ülke paralarına veya onun yerine geçen her türlü ödeme araçlarına (çek, poliçe, emre yazılı senet, hazine bonoları, hisse senedi ve tahvil gibi) döviz denir (Polat, 2015: s.3). Bu değerin yerli para birimi karşısındaki değerine ya da onlar karşısındaki değişim oranına da döviz kuru denir ve ulusal paranın değiştirilebileceği yabancı para miktarını gösterir (Oksay, 2001: s.6).

Makroekonomik istikrarı (işsizlik, enflasyon, büyüme gibi) yakından etkilediğinden döviz

\begin{abstract}
This paper aims to investigate how crude oil price change affects exchange rate volatility both in the short and long run for Turkish economy. For this purpose we employed crude oil price and exchange rate monthly data that covers the period of 1985M01-2015M11. Firstly short and long run relation between two series is investigated by ARDL bound testing approach and our results show that there is co-integration among variables that means two series move together in the long run. According to results, the effect of crude oil price change on exchange rate volatility in the long-run analysis is found negative statistically significant. However, in the short run analysis coefficient of error correction term is seen statically significant and negative. Therefore, the deviation among the variables converge to each other in the long-run equilibrium level. In the last section of paper we apply the newly developed causality in variance test monthly data from $1985 \mathrm{M} 01$ to $2015 \mathrm{M} 11$. The variance causality test shows that oil market volatility spills on the exchange rate in Turkish economy.
\end{abstract}

Key Words: Oil Price, Exchange Rate, Co-Integration Analysis, Causality Test 
vd., 2004: s.3). Döviz kurlarında meydana gelen dalgalanmaları değerlendirip müdahale etmek, kur oynaklığının sermaye hareketleri, dış ticaret dengesi ve üretim, yatırımlar ve faiz oranları üzerinde olumsuz etkileri olabileceğinden dolayı önem arz etmektedir.

Kur istikrarı döviz kurlarında aşııı dalgalanmaların bulunmaması (Neal, 1996: s. 43) şeklinde tanımlanırken, diğer bir görüşe göre dalgalanmaların az olmasından ziyade cari kur ile olması gereken kurun birbirine yakın olmasını şeklinde tanımlanmıştır (Öztürk, 1992: s. 6-7). Yine sermaye hareketlerine açık bir ekonomide reel kurlardaki şiddetli ve düzensiz değişimlerin giderilmesi de kur istikrarı olarak düşünülebilir (McKinnon, 1984: s. 20). Son olarak kur istikrarını gerçekçi kur politikaları sonucunda reel değerine ulaşması olarak gören yaklaşımların yanı sıra kurların seyrinin ülkenin makroekonomik seyri ile uyumlu hareket etmesi şeklinde tanımlayan yaklaşımlarda mevcuttur (Erez, 1994: s. 5).

Kurlardaki aşırı oynaklık uluslararası yatırımcıların cesaretini kırmak, risk pirimini arttırmak suretiyle risk iştahını azaltarak sermaye hareketlerini kısıtlayıcı etki yapabilir, satılan malların maliyetinin artmasına neden olabilir. Yabancı yatırımcı girişi ve yabancı finansal varlıklara olan talep azalabilir. Yine kur oynaklıkları uluslararası şirketlerin projelerinde beklenen karı azalttığı için firmalar yeni yatırımlara girişmekte isteksiz olabilirler. Uluslararası ekonomik ve mali işlemlerde ticari riski arttırabilir, uzun vadeli sermaye akımlarını güçleştirebilir (Türkcan, 982, s.12). İkinci olarak kurlarda meydana gelen aşırı değerlenme, malların maliyetlerine risk piriminin dahil edilmesiyle ihracatı ve üretimi olumsuz etkilerken, Türk lirasının denge değerinin altına düşmesi büyümeyi ve enflasyonu olumsuz etkilemeye başlayabilir. Üçüncü olarak yüksek kur oynaklığı uluslararası ticarette kar getirici unsurlar ile ilgili belirsizlikleri arttırarak ve yatırımların riskini arttırarak yatıımları düşürücü etki yapabilir (Güloğlu ve Akman, 2007: s.44). Dördüncüsü Türkiye ekonomisinde üretim önemli ölçüde hammadde ve ara malı ithalatına dayanmaktadır. Yine ileri teknolojili mallarda da dış bağımlılık yüksektir. Dolayısıyla kurdaki yükselişlerin üretim maliyetlerini arttırması ve bunun da enflasyon üzerinde baskı yaratması söz konusudur. Artan girdi fiyatları diğer yandan yerli üretimi olumsuz etkileyecek, ihracat maliyetleri aratacak ve ihracatta meydana gelen düşüşler ödemeler bilançosunu kötüleştirebilecektir. Bu durum tekrardan kurları dalgalanmaya itecek ve süreç kısır döngüye girebilecektir. Beşincisi kurlardaki dalgalanmalar göreli fiyat yapısındaki ve finansal değişkenlerdeki hareketliliği arttırarak kaynak dağılımını bozabilir. Aşırı kur dalgalanmalarında kurlar, fiyat disiplinini sağlamada yerli politikalara yardımcı olma özelliğini kaybeder. (Neal, 1996: s.44). Altıncı olarak döviz kuru getirisi ve faiz oranı oynaklığı karşılıklı olarak birbirini pozitif yönde etkileyebilmektedir (Öztürk, 2010: s.62). Dolayısıyla Merkez Bankasının kurlardaki dalgalanmayı, makroekonomik hedeflere zarar vermeyecek şekilde belli aralıklar içinde tutması önemlidir. Ayrıca son yaşanan küresel finansal krizle birlikte finansal piyasalarda meydana gelen dalgalanmalar, riskten korunma ve spekülatif güdüler, piyasalardaki hareketlerin tahmin edilmesine yönelik ilgiyi arttırmıştır. Piyasalardaki oynaklığın (volatilite) nelerden kaynaklandığını tahmin edebilmek ve öngörebilmek piyasalarda finansal başarının gerekli koşullarından birisi haline gelmiştir (Güloğlu ve Akman, 2007: s.45).

Döviz kurlarındaki oynaklığın etkileri döviz kuru geçiş etkisi çerçevesinde ele alınabilir. Bu etkiyi İhracatçı ve ithalatçı ülke arasındaki döviz kurlarındaki \%1'lik değişme karşısında, ulusal para cinsinden ithalat fiyatlarındaki oransal değişme olarak da tanımlamak mümkündür (Krugman ve Obstfeld, 2000: s. 468). İkinci bir tanımda nominal döviz kurundaki dalgalanmanın ithalat fiyatlarında neden olduğu değişme etkisidir (Hooper ve Mann, 1989: s. 299). Diğer bir tanımda geçiş etkisi, döviz kuru değişimlerinin hedef (ihracatın yapıldığı ya da ithalatı yapan) ülke parası cinsinden dış ticareti yapılan malların fiyatlarına ne ölçüde yansıdığını bize anlatır (Menon, 1996: s. 434). Dolayısıyla geçiş etkisi, döviz kurlarındaki oynaklığın ithal mal ve hizmet fiyatlarına etkisi ya da daha genel değerlendirildiğinde, yurt içi fiyatlara etkisi bakımından analiz edilebilir (McCarthy, 1999). Döviz kurları yurt içi fiyatları, ticarete konu olan nihai malların ve ithal hammadde ve ara malların fiyatları yoluyla ve ayrıca bunların enflasyon bekleyişleri kanalıyla etkileyebilir (Ho ve McCauley, 2003: s. 4).

Döviz kuru geçiş etkisi teorik olarak Tek Fiyat Kanununa (TFK) ve Satın alma Gücü Paritesi (SGP) teorisine dayanmaktadır. İlk teoriye göre ulaştırma maliyetleri ve ticaret engellerinin olmadığı rekabetçi piyasalarda ticarete konu olan bir mal veya hizmetin mevcut döviz kurundan ulusal paraya çevrilmiş fiyatı dünyanın her yerinde aynıdır ve bu $P_{i}^{d}=P_{i}^{f} \square E$ şeklinde ifade edilir. $P_{i}^{d}$ i malının yurt içi fiyatını, $P_{i}^{f}$ 
malın yurt dışı fiyatını ve E döviz kurunu gösterir. Eğer piyasalar arasında fiyat farkı oluşursa ancak taşıma giderlerinden kaynaklanabilir. İkinci teoriye göre ise iki ülke parası arasındaki döviz kuru ülkelerin fiyatlar düzeyi oranına eşit olmalıdır. Yani SGP, tek fiyat kanununun döviz piyasalarına uyarlanmış halidir. Tüm mallar dış ticarete konu olduğunda SGP teorisine göre döviz kuru, yurt içi ve yurt dışı fiyatlar düzeyi tarafından eş anlı olarak belirlenecektir ve $E=P^{d} / P^{f}$ olacaktır. Burada $P^{d}$ yurt içi fiyat endeksini, $P^{f}$ yurt dışı fiyat endeksini göstermektedir (Krugman ve Obstfeld, 2000: s. 395; Seyidoğlu, 2009: s. 421). Ancak gerçek hayatta ulaştırma maliyetleri ve ticari engeller olduğundan her iki teori yeniden düzenlendiğinde $P^{d}=\alpha \cdot E \cdot P^{f}$ olacaktır. Burada ' $\alpha$ ' reel döviz kurudur. Bu değer zaman içinde değişmezse, belirli bir mal sepetinin ortak para cinsinden fiyatı iki ülkede de aynı yönde değişecek, böylece göreceli SGP (TFK) geçerli olacaktır (Goldberg ve Knetter, 1997). Bu kural geçerli olduğunda döviz kuru dalgalanmaları yurt içi fiyatlardaki oransal değişimlere yansıyacak, yani tam geçiş etkisi söz konusu olacaktır çünkü burada önemli olan göreceli değişimlerdir. Bu yaklaşımına göre kurlardaki oransal değişim, iki ülke arasındaki enflasyon farkına eşit olur ve $\pi_{t}^{d}-\pi_{t}^{f}=\left(E_{t}-E_{t-1}\right) / E_{t-1}$ ile ifade edilir. Denklemde E döviz kuru, t zaman, $\pi^{d}$ yurt içi enflasyon, $\pi^{f}$ yurt dışı enflasyon oranıdır. (Krugman ve Obstfeld, 2000: s. 396; Seyidoğlu, 2009: s.422-25). Yapılan gözlemlerde SGP'nin geçerliliğinin; kur ve fiyat değişimleri arasındaki zaman farkının, sermaye hareketlerinin ve hükümetlerin döviz kuruna müdahalelerinin etkisiyle düşük olduğu görülmüştür. Buna göre dışsal şoklara (petrol fiyatları gibi) döviz kurları hızlı tepki verirken, fiyatların uyumu uzun dönemde gerçekleşmektedir. Uzun dönemde ve özellikle yüksek enflasyon ortamında ise kur değişmeleri ile SGP arasında uyum olduğu görülmektedir (Seyidoğlu, 2009: s. 426).

Yapılan ampirik çalışmalarda emtia ürünlerinden ziyade hammaddelerin ve ara malların döviz kuru geçiş etkisi sergileyerek tam arbitraj kuralına uyduğu kabul edilmektedir. Yani bu tip ürünlerde dışsal şoklar kur üzerinden etkili olabilmektedir. Bu hammadde ve aramalı ana gurubunda yer alan en büyük kalemlerden biri de enerjidir. Türkiye'nin ithal enerji kaynaklarına bağımlıı̆ı̆ petrolde yaklaşık \%85, doğal gazda $\% 90$ civarındadır. Ayrıca günümüzde ham petrol pek çok sanayi dalında temel hammadde olarak kullanılmakta, petrol türevlerinden binlerce çeşit ürün elde edilmektedir. Dolayısıyla hem petrol fiyatlarının kendisindeki artış hem de petrol fiyatlarındaki artışların yurt içi döviz talebini arttırması ve kurlar üzerinde yukarı yönlü baskı oluşturması kanalıyla yurt içi enflasyon üzerinde ikili bir baskı oluşmaktadır. Döviz kurundan yurt içi fiyatlara geçiş etkisi ithal tüketim malları, sermaye malları ve ithal girdi fiyatları yoluyla olabileceği gibi yabancı para cinsinden olan yurt içi mal/hizmet fiyatları yoluyla da olabilir. Yine kurlardaki artış enflasyon beklentisini ve ücret taleplerini artırarak enflasyon üzerinde yeniden bir etki meydana getirebilir (Özdamar, 2015: s. 67-69). Örneğin, petrol fiyatlarındaki artış ithalatçı ülkelerin ödemeler dengesini bozmakta ve böylece ithal malları pahalılaşırken ihraç malların değerinin düşmesi, başka bir ifadeyle reel milli gelirin düşmesine neden olmaktadır. Merkez bankasının para politikalarında bir değişikliğe gitmemesi halinde, nominal döviz kuru yükselmekte ve bu durum, petrol ithal eden ülkelerin, ülke varlıklarının değerini düşürmekte ve $A B D$ dolar bazı ı uluslararası rezerv gereksinimi artmaktadır (Lebe ve Akbaş, 2015: s. 172-173).

Petrol şoklarının makroekonomi üzerindeki etkileri 1973 ve 1979 petrol krizlerinden sonra dikkat çekmeye başlamış ve konu üzerinde çalışmalar artmıştır. Petrol krizlerinin de etkisiyle dünyada neo liberal politikalara ilgi artmış ve Türkiye ekonomisinde de 1980 dönüşümü ile söz konusu politikalar uygulanmaya başlanmıştır. Bu kapsamda devletin ekonomideki ağılığının azalması, sermaye hareketlerinin ve finansal piyasaların serbestleşmesi, faizlerin ve kurların serbest piyasada belirlenmesi, 1989 yılında konvertibilteye geçiş gibi uygulamalar ve dolarizasyon olgusu nedeniyle kur politikalarının (rejimlerinin) önemi artmıştır. Bu yeni süreçte hem Türkiye'de hem dünyada çeşitli krizler yaşanmıştır. Bunlardan önemlileri 1982 Şili ve Meksika Krizi, 1992 Avrupa Para Sistemi Krizi, 1994 Meksika krizi 1997 Asya krizi, 1998 Rusya krizi, 2001 Türkiye ve Arjantin krizleri ve 2008 küresel finansal kriz sayılabilir. 1980 öncesi dönemde sabit kura dayalı rejim uygulanırken 1980 sonrasında daha gerçekçi ve esnek kur rejimine geçilmiş, ancak uygulamada diğer piyasa katılımcıları tam olarak piyasaya müdahil olmadığı için kontrollü esnek kur rejimi uygulanmıştır. 1989 tam konvertibiliteye geçiş, 1991 Körfez krizi ile artan petrol fiyatları ve artan kamu açıkları Merkez Bankasını (MB) parasal genişlemeye zorlamış ve 1993'te kurlar aşırı değerlenmiş, cari işlemler açığı ciddi olarak artmış ve 1994 krizi patlak vermiştir. Kriz sürecinde TL \%70 oranında devalüe edilmiştir. 
Bu krizden sonra kurlarda istikrarın sağlanması için enflasyon kadar değer kaybı politikası izlenmiş, aylık kur hedefleri açıklanmış, likidite sıkı kontrole alınmış, döviz rezervleri güçlendirilmiştir. Ancak 1997 Asya Krizi ve 1998 Rusya krizi nedeniyle küresel finans piyasalarında dalgalanma artmış, ihracat yavaşlamış, döviz kurlarında tekrar dalgalanma yaşanmıştır. MB bu süreçte artan döviz talebini karşılayarak olası bir krizi önlemiştir. Bu krizlerin etkisi ile düşen petrol fiyatları ithalat baskısını hafifletse de, 1999 yılında yaşanan ekonomik daralma, deprem felaketi ile birleşince kamu açıklarının başını çektiği yapısal sorunlar ağırlığını iyice hissettirmiş, cari işlemler açığı tekrar tehlikeli seviyelere artmaya başlamış, enflasyon yüksek kalmaya devam etmiştir. Nisan 1999 seçimlerinden sonra kurulan yeni hükümet Aralık 1999 da IMF ile stand-by anlaşması imzalamıştır. Bu çerçevede yıllardır kronikleşen enflasyonu düşürmek için yapısal reformların yanı sıra hedefe uygun para ve kur politikası benimsemiş (para kurulu esasına göre çalışan hareketli çapa-crawling peg), 1.5 yıl boyunca $1 \$+0,77 €$ 'dan oluşan döviz sepetine TL'nin değeri ilan etmiştir. Ancak enflasyonun düşmemesi, yeterli döviz girişinin olmaması, yapısal reformların geç kalması ve petrol fiyatlarında yaşanan hızlı artış gibi nedenlerle Şubat 2001 'de kurlar serbest bırakılarak

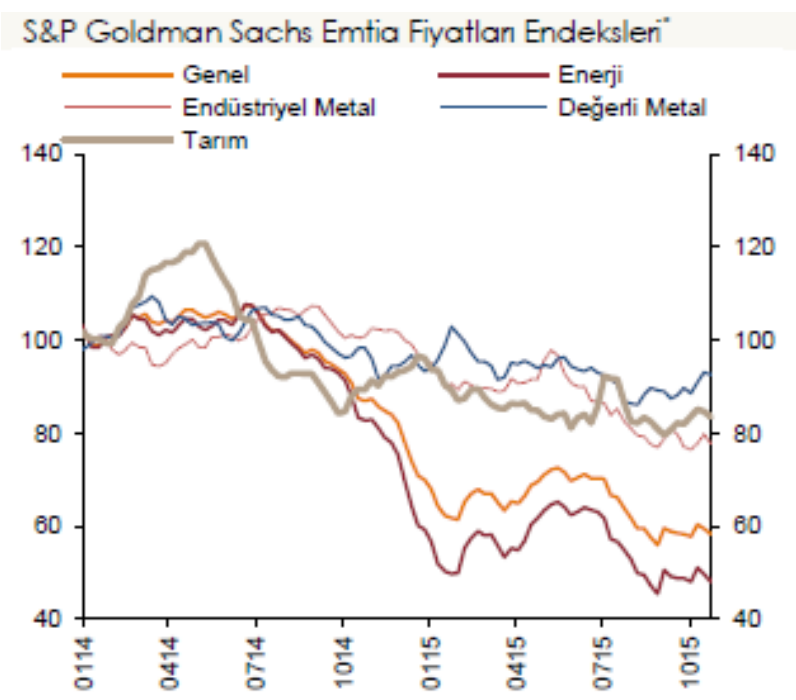

program terkedilmiş ve TL \%40 devalüasyona uğramıştır (Özçam, 2004: ss. 6-12). 2008 yılında meydana gelen finansal krizle birlikte yeni bir döneme girilmiştir. Büyüme, işsizlik, faiz oranları, emtia fiyatları, döviz kurları gibi makro göstergeler yaşanan şoklar neticesinde dalgalanmaya başlamış ve küresel oynaklık önemli derecede artmıştır. Söz konusu oynaklığın, uzun dönem denge değerine gelinceye kadar devam etmesi beklenmektedir. Gelişmiş ve gelişmekte olan ülkelerdeki talep daralmasına bağlı olarak özellikle Çin ekonomisinde görüldüğü gibi ortaya çıkan ekonomik yavaşlama, üretim artışı, küresel ticaretteki düşüş ve piyasalarda yakın gelecekte toparlanmanın yavaş gerçekleşeceği beklentisi, Şekil 1'de görüldüğü gibi petrol ve emtia fiyatlarında (enerji dahil) önemli düşüşler meydana getirmiştir. Özellikle ham petrolün fiyatı 2014'te 115 dolardan 2016 Ocak itibariyle 30 dolar seviyelerine inmiş ve son 12 yılın en düşük düzeyine gerilemiştir (TCMB Enflasyon Raporu 2015-IV). Bunda $A B D$ 'nin kaya petrolü üretimini artırması, OPEC'in üretimini kısmaması, artan enerji verimliliği, küresel ekonominin zayıf görünümü, Çin ekonomisindeki yavaşlama, fiyat savaşları, FED'in faizleri arttırması ile $A B D$ dolarının değer kazanması gibi faktörler etkili olmuştur (Eraydın, 2015).

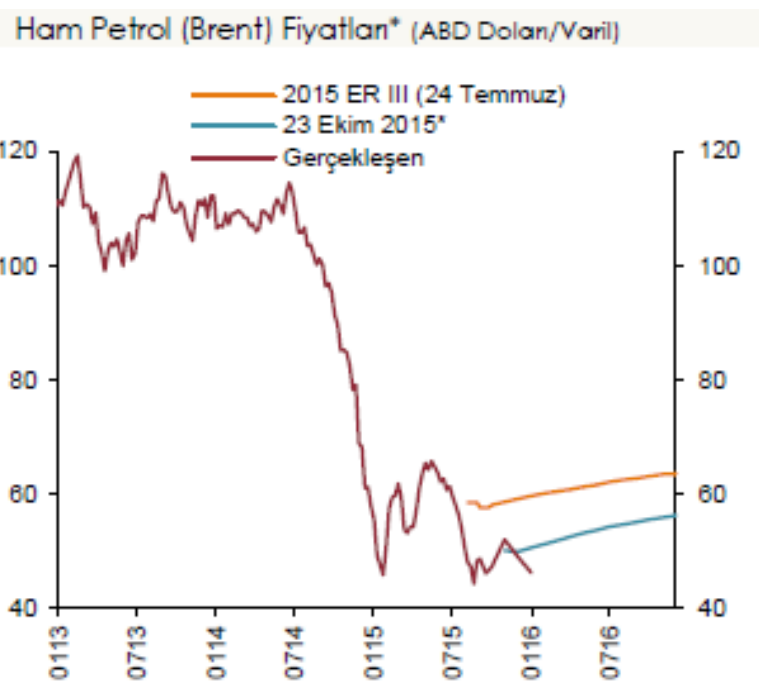

Şekil 1: Ham Petrol Fiyatı ve Emtia Fiyat Endeksi

ABD merkez bankası 2015 sonunda politika faizlerini 25 bp artışla 0,25-0,50 aralığına çıkarmıştır. Bunun anlamı tüm dünyada doların anavatanına dönmeye başlaması ve tüm para birimleri karşısında değerinin artma eğilimine girmesi demektir. İkincisi tarihsel olarak bakılırsa petrol fiyatları ve ABD doları ters yönlü hareket etmektedir. $A B D$ dolarının değer kazanması, petrol ve emtia fiyatlarında gerilemeye yol açarken, tersi durumda hem petrol ve emtia fiyatları artmaktadır (Eraydın, 2015). 

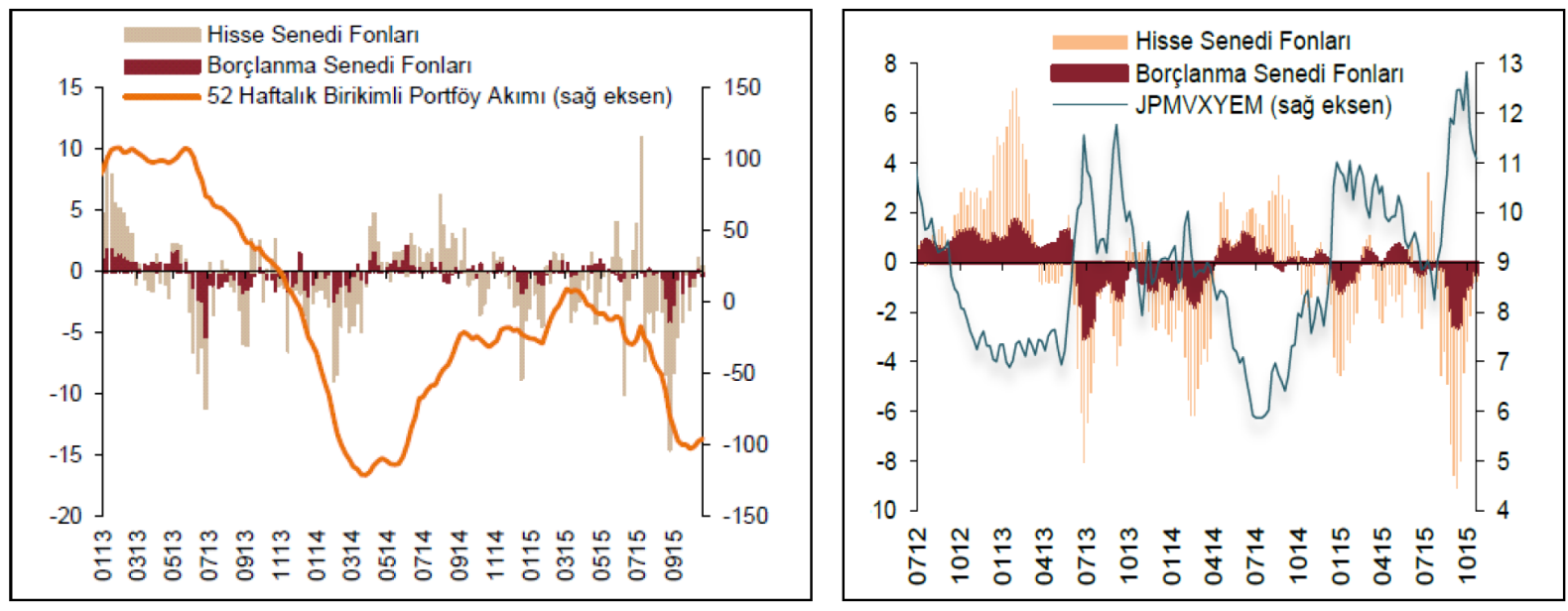

Şekil 2: GOÜ'lere Haftalık Fon Akımları (Milyar ABD Doları), Portföy Akımları (Hisse Senetleri ve Borçlanma Senetleri, Milyar ABD Doları) ve Döviz Kuru Oynaklık Endeksi (JPMVXYEM)

Bu iki etki ile birlikte, küresel ekonomideki zayıf görünüm, Çin ekonomisindeki yavaşlama, risk iştahındaki (VXY endeksi) bozulma ile birleşince hisse senedi ve borçlanma senedi piyasalarından sermaye çıkışları hızlanmış ve Şekil 2'de görüldüğü gibi döviz kurlarındaki oynaklık artmıştır. (TCMB Enflasyon Raporu 2015-IV).

\section{LITERATÜR ÖZETI}

Ham petrol fiyatları ve döviz kuru oynaklığı arasındaki ilişki klasik regresyon modelleri, panel veri modelleri, doğrusal zaman serisi modelleri ve doğrusal olmayan zaman serisi modelleri kullanılarak incelenmiştir. Ancak ekonomik krizlerin piyasalarda meydana getirdiği dalgalanmaları dikkate alan yüksek frekanslı (günlük veya haftalık gözlemler) çalışmalar döviz kuru, faiz oranı, enflasyon gibi değişkenlerde varyansın zaman içinde sabit kalmadığını, göstermiştir. Bu yüzden sabit varyans kabulü üzerine kurulan standart zaman serisi modelleri yerine varyanstaki değişime izin veren modeller kullanılmaya başlanmıştır. Illk olarak zamana göre değişen oynaklığın tahmini için Engle (1982) tarafından Otoregresif Koşullu Değişen Varyans $(A R C H)$ modeli geliştirilmiş, bu model Bollerslev (1986) tarafından otoregresif haraketli ortalama modeline dönüştürülerek Genelleştirilmiş $\mathrm{ARCH}$ $(G A R C H)$ modeli elde edilmiştir. Daha sonra çeşitli makro göstergelerde bu modeller de kullanılarak oynaklık etkisinin varlığı incelenmeye başlanmıştır (Ünal, 2009: s.2).

Aysoy ve Diğerleri (1996) ABD doları ve Alman markı için kur oynaklığını ve haftanın günleri etkisini araştırmıştır. Ulaşılan bulgulara göre serilerde koşullu varyansın geçerli olduğu ve serilerde hafta günleri etkisinin önemli ölçüde bulunduğu görülmektedir. Ayrıca finansal kriz için kukla değişken kullanarak tahmin edilen $\operatorname{GARCH}(1,1)$ modeline göre her iki kurun getiri oranlarının kriz dönemleri hariç düşük oynaklık sergilemiştir.

Domaç ve Mendoza (2002) merkez bankalarının döviz piyasasına alım ve satım şeklindeki müdahalelerini EGARCH modeli ile analiz etmiş, yapılan genel müdahalelerin kurdaki oynaklığı düşürdüğünü, alım ve satım yönündeki müdahalelerin ayrı ayrı etkisinde ise oynaklıkta meydana gelen düşüşün satım yönündeki müdahalelerden kaynaklandığını, alım yönündeki müdahalelerin ise oynaklık seviyesi üzerinde kayda değer bir etkisinin olmadığını göstermiştir.

Ağcaer (2003) Merkez Bankasının ihale ve doğrudan müdahaleişlemlerinin ABD doları dövizkuru üzerindeki etkisini $\operatorname{EGARCH}(1,1)$ modeli kullanarak incelemiş Merkez Bankasının bu işlemlerinin döviz kuru oynaklığı üzerinde etkili olduğunu belirlemiştir. Ancak, Domaç ve Mendoza (2002) tarafından öne sürülenin tersine, alış yönündeki müdahalelerin kur oynaklığı üzerinde etkin olduğu, satış yönündeki müdahalelerin ise etkili olmadığını göstermiştir.

Özçam (2004) çalışmasında GARCH sürecini kullanarak döviz-faiz-borsa üçlüsünde meydana gelen oynaklıkların birbirleri ile olan etkileşimlerini incelemiş ve değişkenlerin oynaklıkları arasında güçlü bir korelasyon bulunmuştur. Ayrıca Merkez Bankası müdahalelerinin kurlardaki oynaklığı arttırmadığı, aksine bir miktar düşürdüğü tespit edilmiştir. 
Ayhan (2006) Türkiye'de uygulanan döviz kuru rejiminin döviz kuru oynaklığı üzerindeki etkisini kur rejimlerini yasal olan ve gerçekte yapılan şeklinde ayırarak $\operatorname{GARCH}(1,1)$ ve $\operatorname{EGARCH}(1,1)$ modelleri ile incelemiş ve sonuçlara göre $\operatorname{GARCH}(1,1)$ modeli şokların neden olduğu oynaklık direncini azalttığı görülmüştür. Bununla birlikte, gerek "yasal olan" gerekse "gerçekte yapılan" sınıflandırmasında "dalgalı kur", "kontrollü dalgalı kur" ve "yönlendirilmiş sabit parite" rejimlerinin oynaklık üzerindeki etkisinin birbirine benzer olduğu bulunmuştur.

Güloğlu ve Akman (2007) ARCH, GARCH ve SWARCH modelleri kullanılarak döviz kuru oynaklığını tahmin etmiş ve SWARCH modeli kullanılarak yapılan incelemede Türkiye ve dünyada yaşanan çeşitli ekonomik ve siyasal olayların döviz kuru oynaklığını etkilediği ve bu oynaklık dönemlerinin kalıcı olduğunu göstermişlerdir.

Öztürk (2010)'ün çalışmasında önce iki değişkenli BEKK modeli ile döviz kuru getirisi ve gösterge kıymet faiz oranı oynaklıkları arasındaki ilişki incelenmiş ve istatistiksel olarak yüksek derecede anlamlı bir ilişki bulunmuştur. Bu iki değişkene ait kovaryans, oynaklığın düşük olduğu dönemlerde sakin bir seyir izlerken oynaklığın yüksek olduğu dönemlerde artış göstermiştir. İki değişken arasındaki nedensellik ilişki (oynaklık yayılma etkisi) Cheung ve $\mathrm{Ng}$ yöntemi ile incelemiş ve karşılıklı nedensellik bulunmuştur.

Ojebiyi ve Wilson (2011) Nijerya ekonomisi için $A B D$ dolar kuru ve petrol fiyatları arasındaki etkileşimi regresyon yöntemi kullanarak analiz etmişlerdir. Tüm periyotu 1999-2003 ve 2004-2009 şeklinde iki alt dönem halinde aylık veriler kullanarak incelemişler ve her iki değişken arasında zayıf da olsa bir korelasyon olduğunu, petrol fiyatlarındaki artışların dolar kurlarındaki oynaklığı küçük düzeylerde arttırdığını tespit etmişlerdir.

Coudert ve Diğerleri (2013) petrol fiyatları ve reel döviz kurları arasındaki ilişkiyi doğrusal olmayan panel veri (panel smooth transition regression) modeli ile 17 'si petrol ihraç eden ve 52'si emtia ihraç eden ülke olmak üzere 1980-2012 dönemi yıllık verileri ile incelemişlerdir. Sonuçlara göre düşük oynaklık rejiminde her iki değişken arasında uzun dönemli eş bütünleşme ilişkisi mevcuttur. Ancak emtia ihraç eden ülkeler için petrol fiyatlarındaki oynaklığın belli bir düzeyi geçmesi, döviz kurlarında uzun dönem dengesine ulaşmayı mümkün kılmamaktadır.
Ogundipe ve Diğerleri (2014) yine Nijerya ekonomisi için petrol fiyatları ve $A B D$ dolar kuru arasındaki etkileşimi johansen eşbütünleşme yaklaşımı ve vektör hata düzeltme modeli çerçevesinde, 1970- 2011 döneminde yıllık verileri kullanarak incelemişlerdir. Sonuçlara göre her iki değişken arasında bir eşbütünleşme ilişkisinin olduğunu ve kısa dönemden uzun döneme petrol fiyatlarındaki belli yüzdede bir artışın kurlarda daha fazla oranda bir dalgalanmaya yol açtığını tespit etmişlerdir.

Shafi ve Diğerleri (2015) Almanya ekonomisi için 1971-2012 dönemi yıllık verileri ile ABD dolar kuru ve ham petrol fiyatları arasındaki ilişkiyi Johansen eş bütünleşme yaklaşımı ve vektör hata düzeltme modelini kullanarak incelemişler ve sonuçta her iki değişkenin eş bütünleşme ilişkisi içinde olduğu tespit etmişlerdir. Sonuçlara göre değişkenler arasında pozitif bir iliş̧ki söz konusudur yani petrol fiyatlarındaki artışlar kurlardaki dalgalanmayı arttırmaktadır.

\section{VERILER VE EKONOMETRIK YÖNTEM}

\subsection{Model ve Veri Seti}

Bu çalışmada Türkiye özelinde ithal ham petrol fiyatları ve döviz kuru oynaklığı arasındaki ilişki nedensellik ve eşbütünleşme yöntemleriyle aşağıdaki model çerçevesinde incelenmiştir;

$d k o=\beta_{0}+\beta_{1} h p f+e_{t}$

Modelde kullanılan "dko" döviz kuru oynaklığını gösterir. Kur $(f x)$ verisi olarak 1 ABD doları karşılığı Türk lirası gösterge niteliğindeki döviz satış kurunun aylık ortalamasını alınmıştır. İkinci adımda aylık kur verilerine logaritmik dönüşüm yapılmış ve bir önceki gözleminden çıkarılarak ( $\left.D k o=\operatorname{lnf} x_{t}-\ln f_{t-1}\right)$ oynaklık verisi elde edilmiştir (Öztürk, 2010). " $h p f^{\prime}$ ifadesi aylık ithal ham petrol fiyatlarını (Monthly Cushing, OK WTI Spot Price FOB Dollars per Barrel) ifade etmektedir. Her iki seri için, mevsimsel etkiler olabileceğinden hareketleyaygın olarak kullanılanTramo/Seat yöntemi ile yapılan araştırma sonucunda söz konusu etkinin serilerde var olmadığı sonucuna ulaşılmıştır. Veriler 1985-2015 dönemini kapsamakta ve 371 gözlemden oluşmaktadır. Çalışmada ABD doları bazlı dünya ham petrol fiyatlarında meydana gelen değişimlerin, döviz kurlarındaki değişimin ne kadarını açıkladığından ziyade, petrol fiyatlarından Türkiye'de döviz kurlarının nominal seviyesine ve döviz kurlarındaki oynaklığa 
(döviz kurlarındaki artış veya azalışların şiddeti) doğru bir eşbütünleşme ve nedensellik ilişkisi olup olmadığı incelenmekte olduğu için nominal değerler alınmıştır. Veriler Merkez bankası ile Enerji Bakanlığının resmi internet sitesinden temin edilmiştir. Serilerin söz konusu zaman dilimi içerisindeki hareketleri grafik 1 'deki gibidir.
DKO

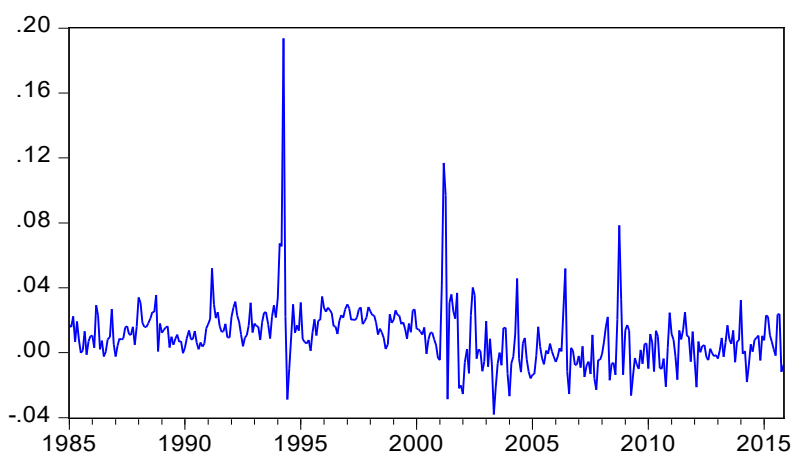

LHPF

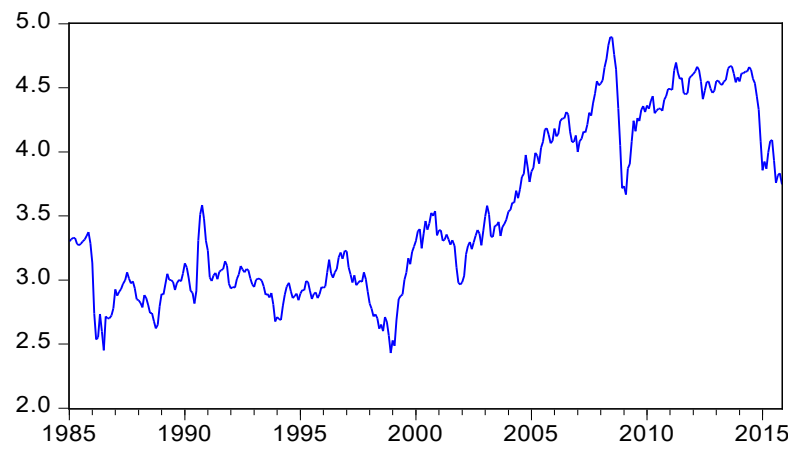

Şekil 3: Döviz Kuru Oynaklığı (Dlfx) ve Ham Petrol Fiyatları (\$/varil)

Çalışmada kullanılan her iki veri için betimleyici istatistikler yani, minimum ve maksimum değerler, standart sapma ve medyan değerleri Tablo 1'de verilmiş ve verilerin dağılımı incelenmiştir. Betimleyici istatistiklerde önce (skewness) ve basıklık (kurtosis) değerlerine bakılabilir. Bunlar verilerin dağılımının normal olup olmadığının incelenmesinde ön bilgi sunar. Skewness yani eğiklik değeri, dağılımın ortalamaya göre simetrisizliğini ifade eder (Doane, Seward: 2011). Döviz kuru oynaklığı ve ham petrol fiyatları için pozitif çıkan skewness değerleri dağılımın hafifçe sağa eğik olduğunu gösterir. Kurtosis değeri (dördüncü moment) ise normal dağılıma göre basıklık veya şişkinliği gösterir (Press ve Diğerleri: 1992). Ham petrol verisi için 3'ten küçük çıkan değer dağılımın basık, döviz kuru oynaklığı serisi için 3'ten büyük çıkan değer dağılımın sivri yapıya sahip olduğuna işaret eder. Normalite konusunda daha kesin yargıda bulunabilmek için Jarque-bera değerleri normal dağılım test sonuçlarına bakılmalıdır. Bu test asimptotik yada büyük örneklem testidir. OLS tahmininden elde edilen kalıntılar kullanılır. 2 serbestlik derecesiyle Ki kare dağılımına sahiptir. Çıkan olasılık değerlerine göre her iki seri için" $\mathrm{H}_{0}$ : hata terimleri normal dağılmaktadır" hipotezi red edilmiştir. Kovaryans ve korelasyon iki değişkenin birbirleri ile ilişkisini ortaya koymak için kullanılmaktadır. Kovaryanstan farklı olarak korelasyon bu ilişkinin derecesini de gösterir. Buna göre döviz kuru oynaklığı ile ham petrol fiyatları arasında negatif yönlü olmak üzere korelasyon değeri \%34 tür.

Tablo 1: Tanımlayıcı İstatistikler

\begin{tabular}{|l|c|c|c|c|c|}
\hline \multirow{2}{*}{ Mean } & LHPF & DKO & \multicolumn{3}{|c|}{ Korelasyon } \\
\cline { 2 - 6 } Median & 3.514647 & 0.010303 & & LHPF & DKO \\
\hline Maximum & 3.306154 & 0.009311 & LHPF & 1 & -0.34605 \\
Minimum & 4.896944 & 0.193704 & DKO & -0.34605 & 1 \\
\hline Std. Dev. & 2.429218 & -0.038144 & & Kovaryans & \\
Skewness & 0.666824 & 0.019341 & & LHPF & DKO \\
\hline Kurtosis & 1.784666 & 27.27349 & DKO & -0.00445 & 0.000373 \\
\hline Jarque-Bera & 35.93282 & 9684.532 & & & \\
Probability & 0.0000 & 0.0000 & & & \\
Sum & 1303.934 & 3.822268 & & & \\
Sum Sq. Dev. & 164.5221 & 0.138405 & & & \\
Observations & 371 & 371 & & & \\
\end{tabular}




\subsection{Birim Kök Testleri}

Çalışmada eşbütünleşme analizi, parametre tahmini ve nedensellik ilişkisine bakılmadan önce kullanılan serilerin birim kök süreci içerip içermediğine bakılmalıdır. Birim kök sürece sahip serilerin kullanılması değişkenlerin birbirlerine olan etkilerinin sağlıklı şekilde ölçülmesini güçleştirecek, regresyon modelinin varsayımları ihlal edilecek ve zaman serilerinin stokastik özellikleri (sabit ortalama, sabit varyans, gecikme seviyesine bağlı kovaryans gibi özellikler) sağlanamayacaktır. Zaten makro iktisat bağlamında kurulu pek çok teori durağanlık varsayımı üzerine kurulmuştur (Wooldridge, 2002). Bu noktada karşımıza üç farklı durum çıkar. Aşağıdaki $A R(1)$ sürecinden hareketle;

$y_{t}=a y_{t-1}+\varepsilon_{t}$

modeli için eğer $a=1$ ise geçmiş dönemdeki şokların etkisi aynen devam eder, $a>1$ ise artarak devam eder ve eğer $a<1$ ise şokun etkisi azalarak devam eder ve bir noktada kaybolur (Enders, 2015). İşte bu katsayının 1'e eşit olması yani şokun etkisinin devam etmesi birim kök sürece işaret eder. Tablo 2 ve Tablo 3'te birim kök testi sonuçları verilmiştir. Durağanlık analizi Schwarz bilgi kriterine göre yapılmıştır.

Tablo 2: Döviz Kuru Oynaklığı Serisi Birim Kök Testi Sonuçları

\begin{tabular}{|c|c|c|c|c|c|c|c|c|}
\hline \multirow{3}{*}{ Testler } & \multicolumn{4}{|c|}{ Düzey } & \multicolumn{4}{|c|}{ Birinci Fark } \\
\hline & \multicolumn{2}{|c|}{ Sabit } & \multicolumn{2}{|c|}{ Sabit ve Trend } & \multicolumn{2}{|c|}{ Sabit } & \multicolumn{2}{|c|}{ Sabit ve Trend } \\
\hline & Test ist. & p değeri & Test ist. & $p$ değeri & Test ist. & p değeri & Test ist. & p değeri \\
\hline DF & -11.526 & 0.000 & -12.158 & 0.000 & & & & \\
\hline ADF & -11.526 & 0.000 & -12.158 & 0.000 & & & & \\
\hline PP & -11.441 & 0.000 & -12.277 & 0.000 & & & & \\
\hline DF-GLS & $-10.928 * * *$ & & $-12.141^{* * *}$ & & & & & \\
\hline Point Optimal & $0.221 * * *$ & & $0.610^{* * *}$ & & & & & \\
\hline Ng-Perron & & & & & & & & \\
\hline $\mathrm{MZa}$ & $-137.04 * * *$ & & $150.964 * * *$ & & & & & \\
\hline MZt & $-8.257^{* * *}$ & & $-8.685 * * *$ & & & & & \\
\hline MSB & $0.061 * * *$ & & $0.057^{* * *}$ & & & & & \\
\hline MPT & $0.212^{* * *}$ & & $0.611^{* * *}$ & & & & & \\
\hline KPSS & 1.221 & & 0.251 & & & & & \\
\hline
\end{tabular}

Tablo 3: Ham Petrol Fiyatları Serisi Birim Kök Testi Sonuçları

\begin{tabular}{|c|c|c|c|c|c|c|c|c|}
\hline \multirow{3}{*}{ Testler } & \multicolumn{4}{|c|}{ Düzey } & \multicolumn{4}{|c|}{ Birinci Fark } \\
\hline & \multicolumn{2}{|c|}{ Sabit } & \multicolumn{2}{|c|}{ Sabit ve Trend } & \multicolumn{2}{|c|}{ Sabit } & \multicolumn{2}{|c|}{ Sabit ve Trend } \\
\hline & Test ist. & $p$ değeri & Test ist. & $p$ değeri & Test ist. & p değeri & Test ist. & $p$ değeri \\
\hline DF & -1.241 & 0.657 & -2.397 & 0.380 & -14.068 & 0.000 & -14.048 & 0.000 \\
\hline$A D F$ & -1.695 & 0.432 & -3.286 & 0.070 & -14.068 & 0.000 & -14.048 & 0.000 \\
\hline PP & -1.521 & 0.528 & -2.947 & 0.149 & -13.586 & 0.000 & -13.564 & 0.000 \\
\hline DF-GLS & $-1.592 * *$ & & $-2.251^{*}$ & & $-13.894^{* * *}$ & & $-13.907 * * *$ & \\
\hline Point Optimal & 4.813 & & 9.135 & & $0.175^{* * *}$ & & $0.572^{* * *}$ & \\
\hline \multicolumn{9}{|l|}{ Ng-Perron } \\
\hline $\mathrm{MZa}$ & -5.230 & & -10.455 & & $-166.765^{* * *}$ & & $-166.744^{* * *}$ & \\
\hline $\mathrm{MZt}$ & -1.590 & & -2.262 & & $-9.113^{* * *}$ & & $-9.123 * * *$ & \\
\hline MSB & 0.304 & & 0.216 & & $0.054^{* * *}$ & & $0.054^{* * *}$ & \\
\hline MPT & 4.760 & & 8.833 & & $0.173^{* * *}$ & & $0.57^{* * *}$ & \\
\hline KPSS & $1.970 * * *$ & & $0.342^{* * *}$ & & 0.077 & & 0.076 & \\
\hline
\end{tabular}

Not: Tablo 2 ve 3'teki değerler, ${ }^{* \prime \prime},{ }^{* * \prime \prime},{ }^{* * * *}$ için sırasıyla $\% 10, \% 5$ ve $\% 1$ 'de anlamlılık düzeylerini göstermektedir. 
Birim kök testi sonuçları Tablo 2 ve 3'te verilmiştir. Sonuçlara göre döviz kuru oynaklığı verisine ait birim kök testi sonuçları "HO: birim kök vardır" hipotezinin tüm testlerde reddedildiğini serinin seviyesinde durağan $I(0)$ olduğunu gösterirken, ham petrol fiyatları serisi seviye değerlerinde $I(0)$ durağan değilken, birinci farkı alındığında I(1) durağan çıktığını göstermiştir.

\subsection{ARDL Sınırlar Testi Yaklaşımı}

Çalışmada kullanılan petrol fiyatları serisi düzey değerinde durağan olmadığından dolayı aralarındaki ilişkiyi sınamak için eşbütünleşme analizinin yapılması gerekmektedir. Böylelikle serilerin uzun dönemde beraber hareket edip etmedikleri tespit edilebilecektir. (Enders, 2015). Eşbütünleşme testlerinde serilerin artık değerlerine dayalı EngleGranger (1997) ve Philips-Ouliaris (1990) yaklaşımı ile modeldeki değişkenlerin içsel olarak alındığı bir sistem yaklaşımı olan Johansen $(1991,1995)$ yaklaşımı yaygın olarak kullanılmaktadır. Tüm bu yaklaşımlarda analiz için serilerin aynı seviyeden durağan olması gerekmektedir. Ancak Pesaran ve Shin (1995) ve Pesaran ve diğerleri (2001) tarafından geliştirilen ARDL sınırlar testi yaklaşımına göre seriler farklı derecelerden örneğin biri I(0) ve diğeri I(1) bütünleşik olsa bile eş bütünleşme ilişkisinin olup olmadığı araştırılabilir (Pesaran ve diğerleri, 2001). Test üç adımda uygulanır. ilk olarak ARDL modeli uygun gecikme sayısına göre oluşturulur. İkinci adımda bu model hata düzeltme modeli olarak dönüştürülür. Son aşamada ise hata düzeltme modeline dayalı kısıtlı ve kısıtsız modeller tahmin edilerek elde edilen hata kareleri toplamları kullanılarak $\mathrm{F}$ istatistiği hesaplanır. Eğer $F$ istatistiği alt sınırın yani $I(0)^{\prime} ı n$ altında ise "eşbütünleşme yoktur" şeklindeki $\mathrm{H}_{0}$ hipotezi kabul, üst sınırın yani I(1)'in üstündeyse red edilir. İki değer arası bölge ise kararsızlık bölgesidir. Kararsızlık bölgesine düşüldüğünde modelin uzun dönem katsayıları tahmin edilip anlamlı ise yorumlanabilir (Saray, 2011).

$$
\begin{gathered}
\text { KIsItlı model; } \Delta y=c+\sum_{j=1}^{p} \propto_{i} \Delta y_{t-j}+\sum_{j=1}^{q} \beta_{j} \Delta x_{t-j}+\epsilon_{t} \\
\Delta y=c+\sum_{j=1}^{p} \propto_{i} \Delta y_{t-j}+\sum_{j=1}^{q} \beta_{j} \Delta x_{t-j}+\epsilon_{t} \\
\text { KIsItsIz model; } \Delta y=c+\delta_{1} y_{t-1}+\delta_{2} y_{t-1}+\sum_{j=1}^{p} \propto_{i} \Delta y_{t-j}+\sum_{j=1}^{q} \beta_{j} \Delta x_{t-j}+\epsilon_{t} \\
\Delta y=c+\delta_{1} y_{t-1}+\delta_{2} y_{t-1}+\sum_{j=1}^{p} \propto_{i} \Delta y_{t-j}+\sum_{j=1}^{q} \beta_{j} \Delta x_{t-j}+\epsilon_{t}
\end{gathered}
$$

Buradaki kIsıtsız model aslında ARDL modelinin hata düzeltme modeli (VECM) şeklindeki ifadesidir. ARDL modelinin VECM'ye dönüştürülmesiyle hem eşbütünleşme ilişkisi araştırılır hem de kısa dönem dengesinde bir sapma olduğunda nasıl düzeltileceği görülebilir. Burada " $c+\delta_{1} y_{t-1}+\delta_{2} y_{t-1}$ " ${ }^{\prime \prime} c+\delta_{1} y_{t-1}+\delta_{2} y_{t-1}$ "ifadesi uzun dönem hata düzeltme mekanizmasını gösterir. $F$ test istatistiğine göre $\delta_{1}=\delta_{2}=0 \delta_{1}=\delta_{2}=0$ ise " $H_{0:}$ eşbütünleşme yoktur" hipotezi kabul edilir (Shresta, Chowdhury, 2005). Modelde maksimum gecikme uzunluğu aylık veriler olduğu için "12" olarak alınmış ve Schwarz bilgi kriterine göre gecikme sayısı "1" olarak belirlenmiştir. Buna göre sabitli ve sabitli / trendli ARDL $(1,1)$ modeli şöyledir;

$$
\begin{aligned}
& D K O=0,010-0,404 * D k o(-1)-0,000701 * H p f+0,000589 * H p f(-1) \\
& (0,00) \quad(0,00) \quad(0,00) \quad(0,00) \\
& D K O=0,011-0,000134^{*} @ T R E N D+0,403^{*} \text { Dko }(-1)-0,000687^{*} \mathrm{Hpf}+0,00614^{*} \mathrm{Hpf}(-1) \\
& \begin{array}{llll}
(0,00) & (0,33) \quad(0,00) \quad(0,00) & (0,00)
\end{array}
\end{aligned}
$$

Modelin tanısal testleri için $X^{2}{ }_{{ }^{\prime} \text { ORM' }} X^{2}{ }_{\mathrm{BG}^{\prime}} \mathrm{X}^{2}{ }_{\text {WHITE }}$ ve $X_{\text {RAMSEY }}^{2}$ testleri kullanılmıştır. Bunlar sırasıyla normallik, otokorelasyon, değişen varyans ve model kurma hatası sınaması istatistikleridir. Buna göre normalite için modelde jarque-bera testi kullanılmıştır. Test istatistiğine göre hata terimleri normal dağılmaktadır. İkinci olarak modelde otokorelasyon görülmemektedir. White testi sonuçları ise değişen varyans olmadığını göstermektedir. Son olarak modelin fonksiyon biçiminin doğru olduğunu (model kurma hatası olmadığını) söyleyen $\mathrm{H}_{0}$ hipotezi, ramsey-reset test sonucuna göre sabitli modelde reddedilirken, sabit ve trendli model için tüm anlamlılık düzeylerinde kabul edilmektedir. 
Tablo 4: $\operatorname{ARDL}(1,1)$ Modeli Tahmin Sonuçları

\begin{tabular}{|c|c|c|c|c|c|c|c|}
\hline \multicolumn{4}{|c|}{ Sabitli Model } & \multicolumn{4}{|c|}{ Sabitli ve Trendli Model } \\
\hline Değişkenler & Katsayı & t istatistiği & Olasılık & Değişkenler & Katsayı & t istatistiği & Olasılık \\
\hline DKO(-1) & 0.40400 & 8.5170 & 0.00 & DKO(-1) & 0.40300 & 8.493 & 0.00 \\
\hline HPF & -0.00070 & -3.4180 & 0.00 & HPF & -0.00687 & -3.341 & 0.00 \\
\hline $\operatorname{HPF}(-1)$ & 0.00059 & 2.8889 & 0.00 & HPF(-1) & 0.00061 & 2.980 & 0.00 \\
\hline \multirow[t]{2}{*}{ C } & 0.01085 & 6.2190 & 0.00 & C & 0.01170 & 5.961 & 0.00 \\
\hline & & & & TREND & 0.00013 & -0.958 & 0.33 \\
\hline \multicolumn{4}{|c|}{ Tanısal Sonuçlar; } & \multicolumn{4}{|c|}{ Tanısal Sonuçlar; } \\
\hline$R^{2}$ & 0.2647 & & & $R^{2}$ & 0.2670 & & \\
\hline $\bar{R}^{2}$ & 0.2592 & & & $\bar{R}^{2}$ & 0.2590 & & \\
\hline $\mathrm{X}_{\mathrm{BG}}^{2}$ & $1.083[0.37]$ & & & $X_{B G}^{2}$ & $1.085[0.37]$ & & \\
\hline$X^{2}{ }_{\text {NORM }}$ & $10847.71[0.00]$ & & & $\mathrm{X}^{2}{ }_{\text {NORM }}$ & $11002.02[0.00]$ & & \\
\hline $\mathrm{X}_{\text {WHITE }}^{2}$ & $46.67[0.00]$ & & & $X_{\text {WHITE }}^{2}$ & $48.56[0.00]$ & & \\
\hline$X_{\text {RAMSEY }}^{2}$ & $9.43[0.00]$ & & & $x_{\text {RAMSEY }}^{2}$ & $9.64[0.00]$ & & \\
\hline
\end{tabular}

Modelde kullanılan serilerde kırılma olup olmadığının ve katsayıların istikrarlı olup olmadığının bilinmesi gerekir. Buna göre ardışık artıklar ile hesaplanan CUSUM testi, seride yapısal kırılmanın olup olmadığı hakkında bilgi verir. Ardışık artıkların kareleri ile hesaplanan bu test kullanılarak belli

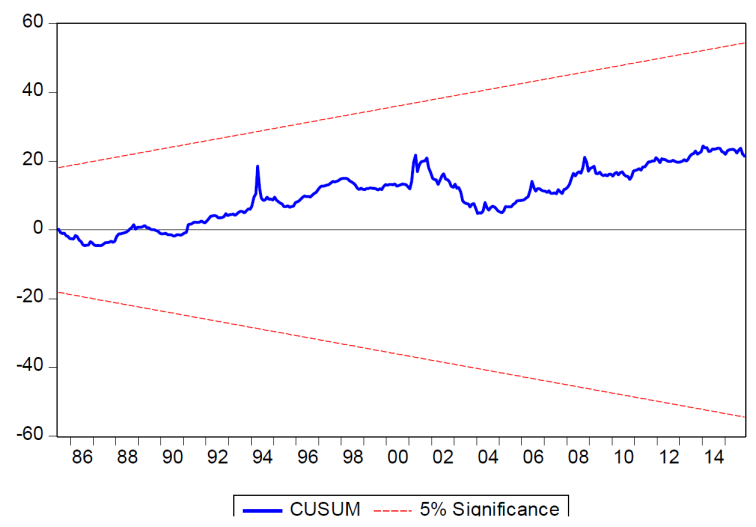

Şekil 4: CUSUM Testi

Şekil 4'te önce sabitli sonra sabitli ve trendli model için yapısal kırılmanın ve modelin istikrarlılığının grafiksel gösterimi sunulmuştur. Görüldüğü gibi her iki modelde de güven aralığı dışına çıkılmadığı için yapısal kırılmanın olmadığı, modelin istikrarlı olduğu söylenebilir. Model tahmin edildikten sonra kısıtlı bir güven aralığında modelin artıklarının grafiği çizilerek güven sınırları tespit edilir. Güven sınırları dışına çıkıldığında (Şekil 4'teki kırmızı çizgiler) yapısal değişiklik olduğuna, aksi durumda ise yapısal değişiklik olmadığına karar verilir.

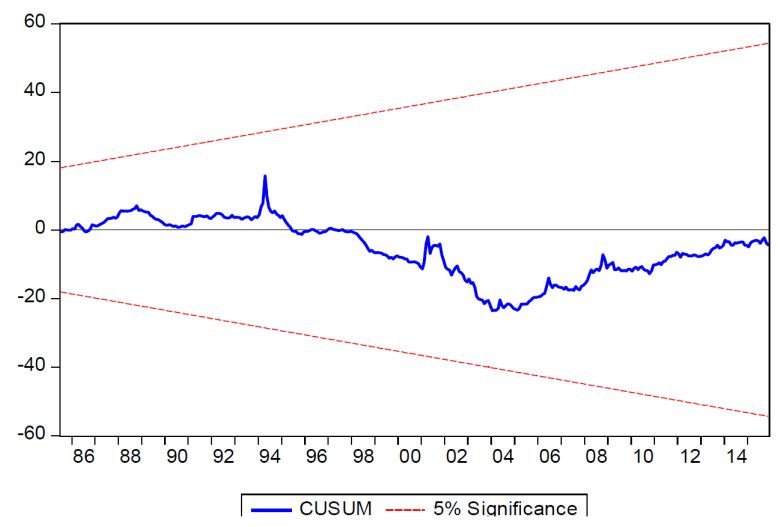

Şekil 4 CUSUM Test Sonuçları

ve kısıtsız modelden gelen hata kareleri toplamı ile F istatistiği hesaplanır ve kritik sınır değerleri ile karşılaştırılır.Tablo 5'de görüldüğü gibi sabitli modelde " $F$ " istatistiği değeri tüm anlamlılık düzeylerinde kritik değerlerin üstündedir. Yani "eşbütünleşme yoktur" şeklindeki sıfır hipotezi reddedilmektedir. 
Tablo 5: Uzun Dönemli Iliş̧kilerin Belirlenmesi için Sınır Testi Sonuçları

\begin{tabular}{|c|c|c|c|c|c|c|c|}
\hline \multicolumn{8}{|c|}{ Sabitli Model } \\
\hline \multirow{2}{*}{ k } & \multirow{2}{*}{ F İst. } & \multicolumn{6}{|c|}{ Kritik Değerler } \\
\hline & & \multicolumn{2}{|c|}{$1 \%$} & \multicolumn{2}{|c|}{$5 \%$} & \multicolumn{2}{|c|}{$10 \%$} \\
\hline \multirow{2}{*}{1} & \multirow{2}{*}{78.98} & $I(0)$ & $\mathrm{I}(1)$ & $I(0)$ & $\mathrm{I}(1)$ & $I(0)$ & $\mathrm{I}(1)$ \\
\hline & & 4.04 & 4.78 & 4.94 & 5.73 & 6.84 & 7.84 \\
\hline \multicolumn{8}{|c|}{ Sabit\&Trendli Model } \\
\hline \multirow{2}{*}{ k } & \multirow{2}{*}{ F İst. } & \multicolumn{6}{|c|}{ Kritik Değerler } \\
\hline & & \multicolumn{2}{|c|}{$1 \%$} & \multicolumn{2}{|c|}{$5 \%$} & \multicolumn{2}{|c|}{$10 \%$} \\
\hline \multirow{2}{*}{1} & \multirow{2}{*}{79.42} & $1(0)$ & $\mathrm{I}(1)$ & $I(0)$ & $\mathrm{I}(1)$ & $I(0)$ & $\mathrm{I}(1)$ \\
\hline & & 5.59 & 6.26 & 6.56 & 7.30 & 8.74 & 9.63 \\
\hline
\end{tabular}

Kritik değerlere göre eş bütünleşme ilişkisinin olup olmadığına karar verildikten sonra kısa ve uzun dönem ilişkilere bakılabilir. Kısa dönem ilişkiyi araştırabilmek için ARDL $(1,1)$ modelinden hesaplanan hata düzeltme modeli aşağıdaki gibi kurulmuştur;

$$
\Delta d k o=c+\propto_{1} t+\propto_{2} h p f_{t-1}+\sum_{j=1}^{p} \propto_{3 i} \Delta d k o_{t-j}+\sum_{j=1}^{q} \beta_{j} \Delta h p f_{t-j}+\epsilon_{t}
$$

Modelde " $c$ " sabit terimi, " $t$ " trend değerini, " $d k o$ " (döviz kurlarındaki oynaklık) bağımlı değişkeni, "hpf" (ham petrol fiyatlarını) bağımsız değişkeni ve ECt-1 değişkeni uzun dönem ilişkisinden elde edilen hata terimleri serisinin bir dönem gecikmeli değeridir. Bu değişkenin katsayısı kısa dönemdeki dengeden sapmanın ne kadarının uzun dönemde düzeltileceğini gösterir (Karagöl ve Diğ, 2007).

Tablo 6: ARDL $(1,1)$ Yaklaşımına Dayalı Hata Düzeltme Modeli Sonuçları

\begin{tabular}{|l|c|c|c|c|c|c|}
\hline \multirow{2}{*}{ Değişkenler } & \multicolumn{3}{c|}{ Sabit Model } & \multicolumn{3}{c|}{ Sabit ve Trendli Model } \\
\cline { 2 - 7 } & Katsayılar & t-ist. & Olasılık & Katsayılar & t-ist. & Olasılık \\
\hline Dhpf & -0.000701 & -3.43 & 0.000 & -0.001315 & -1.02575 & 0.000 \\
\hline C & 0.000 & 0.000 & 1.000 & 0.000134 & 0.000864 & 0.980 \\
\hline ECMC(-1) & -0.595 & 0.047 & 0.000 & -0.596 & -12.638 & 0.000 \\
\hline
\end{tabular}

Tablo 6'da görüldüğü gibi hem sabitli hem de sabit ve trendli modelde ham petrol fiyatlarındaki değişimin döviz kurları üzerindeki kısa dönem etkisi negatifve istatistiksel olarakanlamlıdır. Hata düzeltme değişkeninin katsayısı ise sabitli modelde -0.595 ve sabit ve trendli modelde -0.596 olarak belirlenmiştir olasılık değerleri istatistiksel olarak anlamlıdır. Buna göre hem sabitli hem de sabitli ve trendli model için ham petrol fiyatlarında meydana gelen bir şokun döviz kurları üzerinde yarattığı etkinin yaklaşık yarısı (\% 60'ı) bir yıl içinde kaybolmaktadır. Narayan ve Smyth (2006) in de çalışmalarında ifade ettiği gibi hata düzeltme değişkeninin katsayısının "1"den küçük olması sistemin yavaş yavaş dengeye geldiğini ifade etmektedir ve bu dalgalanma her seferinde azalarak uzun dönemde dengeye dönüşü sağlayacaktır.

Eş bütünleşme ilişkisinin varlığı durumunda " $\beta$ " katsayılarının ( $\left.y=\beta x_{t}+\varepsilon\right)$ doğru şekilde tahmin edilmesi gerekmektedir. Eş bütünleşme parametrelerinin ( $\left.\beta^{\prime} \mid a r ı n\right)$ tahmininde genellikle şu dört yöntem ağırlıkı olarak kullanılmaktadır; EngleGranger, Philips-Ouliaris ve ARDL (OLS tahmincisini kullanır), Johansen (ML tahmincisini kullanır). Eş bütünleşe ilişkisi bu çalışmada ARDL yöntemi ile belirlendiği için eş bütünleşme parametrelerinin tahmininde bu yöntem kullanılmıştır. 
Tablo 7: ARDL $(1,1)$ Modelinin Uzun Dönem Sonuçları

\begin{tabular}{|cccc|cccc|}
\hline & \multicolumn{3}{c|}{ Sabit Model } & \multicolumn{3}{c|}{ Sabit ve Trendli Model } \\
\hline Değişken & Katsayı & t-ist. & Prob. & Değişken & Katsayı & t-ist. & Prob. \\
\hline Hpf & -0.000187 & -3.88 & 0.0000 & Hpf & -0.000123 & -1.47 & 0.1400 \\
C & 0.01822 & 7.26 & 0.0000 & C & 0.01964 & 6.75 & 0.0000 \\
\hline
\end{tabular}

Tablo7'deiseARDL $(1,1)$ uzundönemeşbütünleşme katsayıları verilmiştir. Ham petrol fiyatları katsayısı her iki modelde de döviz kuru oynaklığı serisi ile negatif ilişkili olduğu görülmektedir. Katsayıların olasılık değerlerine bakıldığında sabitli modelde ham petrol fiyatları serisi katsayısı anlamlı iken, sabitli ve trendli modelde anlamlı çıkmamıştır. Elde edilen uzun dönem katsayılarına göre ham petrol fiyatlarında meydana gelecek \%1 br'lik artışın Türkiye'de döviz kuru oynaklığını (kurdaki dalgalanmayı) \%0.0187 br. oranında azalttığı söylenebilir. Kur oynaklığı katsayısı yorumlanırken küçük değer almış olsa bile, Türkiye ekonomisinin büyüklüğü ve tüketim hacmi dikkate alındığında anlam kazanabilir.

\subsection{Varyantsa Nedensellik (Volatility Spillover)}

Eş bütünleşme ilişkisi belirlendikten sonra her iki seri arasında nedensellik ilişkisinin olup olmadığı araştırılmıştır. Nedensellik ilişkisinin belirlenmesinde kullanılan çeşitli yöntemler mevcuttur. Ancak çalışma için seçilen varyansta nedensellik testi diğer nedensellik testlerinden önemli ölçüde ayrılmaktadır. Literatürdeki Engle-Granger nedensellik, Doğrusal olmayan Granger nedensellik, Hata Düzeltme Modeline dayalı, (VECM) nedensellik, Toda-Yamamoto ve Bootstrap Toda Yamamoto yaklaşımı, zamana göre değişen (time varying) nedensellik gibi nedensellik testlerinde hata terimi ortalamalarında nedensellik test edilirken, bu yöntemde varyansta nedensellik test edilmektedir. Standart ekonometrik modellerde hata terimi varyansı sabit kabul edilmektedir. Ancak pekçok iktisadi ve finansal zaman serisi büyük kriz dönemleri ile birlikte dalgalanmaya girmekte ve sabit varyans varsayımı geçerli olmamaktadır. Diğer nedensellik testleri iki değişkenin varyansında meydana gelen değişikliklerden kaynaklanan oynaklık yayılma etkisini ölçmede yetersiz kalmaktadırlar. Cheung ve $\mathrm{Ng}$ (1990, 1996), Engle ve Diğerleri (1990), Engle ve Susmel (1990), Hamao ve Diğerleri (1990), Hafner ve Herwatz (2008), Granger ve Diğerleri (1986), Lin ve Diğerleri (1994) ve King ve Diğerleri (1994) yaptıkları çalışmalarda varyansta oynaklığı dikkate almışlardır. Özellikle finansal piyasalardaki veya makro iktisadi alanlardaki çeşitli aktiflerde yada büyüklüklerde, varyansta oynaklığın tespit edilmesi ve açıklanması, nedensellik ilişkilerini daha iyi izah edebilecektir. Eğer araştırmacı varyansta oynaklık unsurunu ihmal ederse, söz konusu aktiflerde veya piyasalarda meydana gelen şokun sadece o aktifte veya piyasada oynaklığı arttırdığını düşünerek, diğer aktifler veya piyasalar üzerindeki etkilerini ihmal etmiş olabilir (Hong, 2001: p.184).

Varyansta ortaya çıkan nedensellik ilk olarak ilgili bilginin yada şokun ortaya çıkışından ve piyasaların bu yeni bilgi veya şoku değerlendirip özümsemesinden kaynaklanmaktadır. Ucuza alıp pahalıya satmanın mümkün olmadığı bir ekonomide (no arbitrage economy) fiyat değişikliklerinden kaynaklanan varyans, piyasaya akan bilgi miktarı ya da şokun derecesiyle yakından ilişkilidir. Küme halinde akan bilgi, piyasa oyuncuları tarafından özümsenip uyum sağlansa bile piyasalarda dalgalanma yaratabilir. Engle, Ito ve Lin (1990), varyanstaki değişiklikleri yeni bir ekonomi politikası uygulanmaya başlandığında, piyasa oyuncularının bu yeni politikaya uygun hareket etmeye başlaması için ihtiyacı olan uyum süresine bağlamaktadır. Piyasa oyuncularının beklentileri ve davranışları yeni politikaya uyum sağladığında artık oynaklık kaybolur (Cheung ve Ng, 1996: p.33-34).

Bu konuda kullanılan iki test yöntemi vardır. İlki Cheung ve Ng (1996) yöntemi, GARCH tahmininden elde edilen standart kalıntılara ait çapraz korelasyon fonksiyonuna (CCF) dayanır. Ancak boş hipotezi test etmek için kullanılan portmanteau testi CCF fonksiyonuna dayalıdır ve oynaklık süreci yanlardan basık şekil aldığında (leptokurtic) küçük ve orta büyüklükteki örneklemler için oversizing (örneklem büyüklüğü) probleminden etkilenir. Bu yöntemdeki ikinci güçlük CCF'ye dayalı oynaklık yayılması testinde sonuçlar VAR modelindeki öncül ve gecikmelerin (lags and leads) derecelerine göre farklı değerler alır (Hafner ve Herwatz, 2008: pp.221-222). İkinci yöntem olan Hafner Herwartz (2006) testi ise LM (Lagrange Multiplier) prensibine dayanır, uygulaması daha basittir ve yukarıda belirtilen sorunlar yaşanmaz. Ayrıca bu yöntemde uygulanan Monte Carlo deneyi, 
LM yaklaşımının küçük örneklemlerde, leptokurtic metoda göre daha sağlıklı olduğunu ve örneklem büyüdükçe daha iyi sonuçlar verdiğini göstermiştir. Diğer yandan öncül ve gecikmelerin derecelerinin CCF fonksiyonunda yanlış seçilmesi durumunda sonuçlarında yanlış olabileceği ve CCF istatistiğinin derecesinin de yanlış seçilme riskini artırdığı belirtilmiştir (Hafner ve Herwartz, 2006: pp. 137-141). Hafner ve Herwartz (2006) yönteminde önce tek değişkenli (univariate) GARCH modeli tahmin edilir. İki değişken arasında varyansta nedensellik yoktur diyen boş hipotez şöyle tanımlanır;

$$
H_{0}: \operatorname{Var}\left(\varepsilon_{i t} \mid F_{t-1}^{(j)}\right)=\operatorname{Var}\left(\varepsilon_{i} \mid F_{t-1}\right) \quad j=1, \ldots, N, i \neq j
$$

Eşitlikteki $F_{t}^{(j)}=F_{t} \backslash \sigma\left(\varepsilon_{j \tau}, \tau \leq t\right)$ ve $\varepsilon_{i t}$ ifadeleri GARCH modelinden gelen artık değerlerdir.

Aşağıdaki model ise $\mathrm{H}_{0}$ hipotezini test etmektedir. Ancak kullanılan seriler durağan olmalıdır. Bu noktada tanımlanması gereken terimler şöyledir;

$$
\varepsilon_{i t}=\xi_{i t} \sqrt{\sigma_{i t}^{2} g_{t}}, \quad g_{i t}=1+z_{j}^{\prime} \pi, \quad z_{j t}=\left(\varepsilon_{t-1}^{2}, \sigma_{t-1}^{2}\right)^{\prime}
$$

$\sigma_{i t}^{2}$ ifadesi koşullu varyanstır ve alternatif hipotez $H_{1}: \pi \neq 0$ 'dır. $\varepsilon_{i t}$ 'nin gausyan $\sigma_{i t}^{2}=\omega_{i}+\alpha_{i} \varepsilon_{i-1}^{2}+\beta_{i} \sigma_{i-1}^{2}$ 'dir. $\xi_{i t}$ IfadesiGARCH log liklehood fonksiyonunun değeri $x_{i t}\left(\xi_{i-1}^{2}\right) / 2$ modelinin standartlaştııımış artık değeridir. Burada 'dir. Burada $x_{i t}^{\prime}$ nin değeri $x_{i t}=\sigma_{i}^{-2}\left(\partial \sigma_{i}^{2} / \partial \theta_{i}\right)$ ve nedensellik yoktur $H_{0}: \pi=0$ boş hipotezine karşı $\theta_{i}$ nin değeri $\theta_{i}=\left(\omega_{i}, \alpha_{i}, \beta_{i}\right)^{\prime}$ 'dir. Her iki değişken arasındaki oynaklık yayılma etkisinin varlığı aşağıdaki LM testine göre araştırılır;

$$
\lambda_{L M}=\frac{1}{4 T}\left(\sum_{t=1}^{T}\left(\xi_{i t}^{2}-1\right) z_{j t}^{\prime}\right) V\left(\theta_{i}\right)^{-1}\left(\sum_{t=1}^{T}\left(\xi_{i t}^{2}-1\right) z_{j t}\right)
$$

Bu denklemde $V\left(\theta_{i}\right)$ nin değeri;

$$
V\left(\theta_{i}\right)=\frac{\kappa}{4 T}\left(\sum_{t=1}^{T} z_{j} z_{j}^{\prime}-\sum_{t=1}^{T} z_{j} x_{i}^{\prime}\left(\sum_{t=1}^{T} x_{i} x_{i}^{\prime}\right)^{-1} \sum_{t=1}^{T} x_{i} z_{j}^{\prime}\right), \quad \kappa=\frac{1}{T} \sum_{t=1}^{T}\left(\xi_{i}^{2}-1\right)^{2}
$$

Burada test istatistiğinin asimptotik dağılımı $z_{\mathrm{jt}}{ }^{\prime}$ deki hatalı belirlenim (misspesifikasyon) göstergelerinin sayısına bağlıdır. $\lambda_{L M}$ 'de bunlardan iki tane olduğu için test istatistiği 2 serbestlik derecesi ile $\chi^{2}$ dağılımı gösterir. Haftner ve Herwartz yönteminde önce $\varepsilon_{\text {it }}$ ve $\varepsilon_{\mathrm{jt}}$ için GARCH (1:1) modeli tahmin edilir. Sonra standartlaştırılmış artıklar $\xi_{i t}^{2}$ ve GARCH modeli türev değeri $x_{i t}$ elde edilir. Üçüncü adımda oynaklık sürecini ifade eden $\mathrm{GARCH}$ modeli varyansı $\sigma_{j t}^{2}$ terimi, $\mathrm{z}_{\mathrm{jt}}$ kullanılarak hesaplanır. Dördüncü adımda $\xi_{i t}^{2}-1$ ifadesi $x_{i t}^{\prime}$ ve $z^{\prime}{ }_{j t}$ deki misspesifikasyon göstergeleri üzerine regres edilir. Bu modelden gelen $\mathrm{R}^{2}$ ile gözlem sayısı T çarpılarak $\lambda_{L M}$ bulunur (Hafner ve Herwartz, 2006: pp. 137-141). Analiz sonuçlarına göre elde edilen ARCH $(1 ; 1)$ ve GARCH $(1 ; 1)$ modelleri sırasıyla şöyledir; 
Tablo 8: ARCH $(1 ; 1)$ ve GARCH $(1 ; 1)$ Modeleri

\begin{tabular}{|ccccc|}
\hline Değişkenler & Katsayılar & St Hata & z İstatistiği & Olasılık \\
\hline $\mathrm{C}$ & 0.004259 & 0.000484 & 8.79471 & 0.00 \\
$\mathrm{Y}(-1)$ & 0.571101 & 0.037883 & 15.07524 & 0.00 \\
\multicolumn{5}{c}{ Varyans Eşitliği } \\
\hline $\mathrm{C}$ & $2.78 \mathrm{E}-05$ & $5.38 \mathrm{E}-06$ & 5.154281 & 0.00 \\
RESID(-1)^2 & 0.67873 & 0.086953 & 7.805735 & 0.00 \\
GARCH(-1) & 0.395233 & 0.045371 & 8.71122 & 0.00 \\
\hline
\end{tabular}

\begin{tabular}{|ccccc|}
\hline Değişkenler & Katsayılar & St Hata & z İstatistiği & Olasılık \\
\hline $\mathrm{C}$ & 0.003303 & 0.003853 & 0.857406 & 0.39 \\
$\mathrm{X}(-1)$ & 0.227576 & 0.064562 & 3.524921 & 0.00 \\
\hline \multicolumn{5}{|c|}{ Varyans Eşitliği } \\
\hline $\mathrm{C}$ & 0.00126 & 0.000502 & 2.508684 & 0.01 \\
RESID(-1)^2 & 0.272668 & 0.054568 & 4.996871 & 0.00 \\
GARCH(-1) & 0.560112 & 0.099723 & 5.616691 & 0.00 \\
\hline
\end{tabular}

Eşitlikte $\mathrm{y}$ kur oynaklığı ve $\mathrm{x}$ ham petrol fiyatları olmak üzere ARCH $(1 ; 1)$ ve GARCH $(1 ; 1)$ modelleri önce y sonra $x$ için sırasıyla şöyledir;

$y=0,004259+0.5711 y(-1)$

$x=0,003303+0.2276 \times(-1)$

$y=0,0000278+0,678 \mathrm{resid}(-1)^{2}+0,395 \mathrm{GARCH}(-1)$

$x=0,001260+0,272 \operatorname{resid}(-1)^{2}+0,560$ GARCH $(-1)$

Buna göre tüm modellerdeki katsayılar, x'in bağımsız değişken olduğu GARCH (1:1) modelindeki sabit terim hariç istatistiksel olarak anlamlıdır. Varyans eşitliklerindeki katsayılar pozitif işaretlidir ve kur oynaklığı hareketinin koşullu varyansı (yani açıklanan değişkenin varyansı) petrol fiyatlarına doğru yakınsama göstermektedir. Koşullu varyans denklemini $\sigma_{i t}^{2}=\omega_{i}+\alpha_{i} \varepsilon_{i-1}^{2}+\beta_{i} \sigma_{t-1}^{2} \quad$ eşitliği

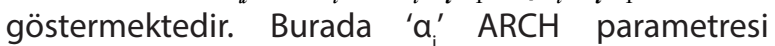
$\left(\operatorname{resid}(-1)^{2}\right)^{\prime} y i$ ve ' $\beta_{i}^{\prime}$ GARCH parametresi $(\operatorname{GARCH}(-1))^{\prime} \mathrm{i}$ göstermektedir ve her iki modelde farklı değerler almıştır. $\alpha+\beta$ ifadesi "1"den küçük ise meydana gelen şokun kalıcılığını (degree of persistence) göstermektedir. "a"katsayısının büyüklüğü oynaklığın piyasa hareketlerine karşı tepkisini verirken, " $\beta$ " katsayısının büyüklüğü oynaklığın oynaklık direncine karsı tepkisini ifade etmektedir (Ünal, 2009). Petrol fiyatlarına ait modelde söz konusu ifade "1"den küçük ve istatistiksel olarak anlamlı iken diğer modelde istatistiksel olarak anlamlı ancak "1"den büyüktür. $A R C H$ ve GARCH değerlerinin büyük olması koşullu varyansın farklı şekillerde ortaya çıkmasına neden olur. Büyük ARCH katsayısı şokun etkisinin de büyük olduğunu, büyük GARCH katsayısı ise şokun etkisinin daha kalıcı olduğunu ifade eder. Dolayısıyla büyük $A R C H$ değeri kısa dönemde oynaklığı artıııcı, büyük GARCH değeri ise uzun dönemde oynaklığı arttırıcı etki yapacaktır (Nazlıoğlu et all. 2013). Çalışmada x'in bağımlı değişken olduğu GARCH modelinde, GARCH $(-1)^{\prime}$ in katsayısı olan 0,5601 ile ARCH katsayısı (resid $\left.(-1)^{2}\right)$ olan 0,2726 karşılaştırıldığında petrol fiyatlarının yarattığı oynaklığın daha çok GARCH etkisinden kaynaklandığı yani uzun dönemde oynaklık etkisi arttığı söylenebilir.

Tablo 9: Varyansta Nedensellik Test Sonuçları

\begin{tabular}{|c|c|c|}
\hline Varyansta Oynaklık & LM İstatistiği & Olasılık \\
\hline Ham petrol fiyatlarından kur oynaklığına doğru & 11.291 & 0.00 \\
\hline Kur oynaklığından ham petrol fiyatlarına doğru & 6.368 & 0.04 \\
\hline
\end{tabular}

Son olarak $\lambda_{L M}$ istatistiği sonuçları değerlendirildiğinde Tablo 9'da görüldüğü gibi ham petrol fiyatlarından döviz kurlarına doğru oynaklık yayılma etkisi söz konusuyken, döviz kurlarından ham petrol fiyatlarına doğru oynaklık yoktur diyen $\mathrm{H}_{0}$ hipotezi \%1'de kabul edilerek oynaklık yayılma etkisinin tespit edilmediği söylenebilir.

\section{SONUÇ}

Petrol fiyatları ve döviz kurları makro iktisadi dengenin sağlanmasında etkili olan iki önemli değişkendir. Ham petrol günümüzde pek çok sanayi dalında temel hammaddedir. 1973 ve 1979 petrol krizleri ülke ekonomilerinin ham petrole ne kadar bağlı olduklarını göstermiştir. Diğer yandan Türkiye gibi yüksek cari açık veren, dış tasarruflara bağlı, hammadde ve ara malları ithalatı yüksek ülkeler için döviz kurlarındaki dalgalanmalar dış ticaret sektörü, istihdam, enflasyon ve ekonomik büyüme gibi pek çok değişkeni olumsuz etkilemektedir. Sonuçlara göre ham petrol fiyatları ve ABD dolar kuru arasında uzun dönemli bir eş bütünleşme ilişkisi tespit 
edilmiştir, yani bu iki değişken uzun dönemde birlikte hareket etmektedirler. Ayrıca petrol fiyatlarındaki dalgalanmadan döviz kuruna doğru bir oynaklık yayılma etkisi söz konusudur. Son dönemlerde petrol fiyatlarındaki aşırı dalgalanma kurlarda yukarı yönlü baskıyı arttırmakta bu da makroekonomik istikrarı bozmakta makro hedeflere ulaşmayı güçleştirmektedir. Dolayısıyla kur politikalarında petrol fiyatlarındaki şokların dikkate alınması faydalı olabilir.

\section{KAYNAKLAR}

Ağcaer, A., (2003), Dalgalı Kur Rejimi Altında Merkez Bankası Müdahalelerinin Etkinliği: Türkiye Üzerine Bir Çalışma, Türkiye Cumhuriyet Merkez Bankası Piyasalar Genel Müdürlüğü, Aralık 2003.

Aysoy, C. ve Balaban, E. (1996), The Term Structure of Volatility in the Turkish Foreign Exchange: Implications for Option Pricing and Hedging Decisions, TCMB Tartısma Tebliğleri No: 9613, April 1996.

Ayhan, D. (2006), Döviz Kuru Rejimlerinin Kur Oynaklığı Üzerine Etkisi: Türkiye Örneği. İktisat İşletme ve Finans, Ağustos, pp. 64-76.

Baum. C. F., Çağlayan, M, Özkan, N. (2004), “Nonlinear Effects of Exchange Rate Volatility on the Volume of Bilateral Exports", Journal of Applied, Vol.19, s. 1-23.

Bollerslev, T., Chou, R. Y. ve Kroner, K. F. (1992), ARCH Modeling in Finance, Journal of Econometrics, 52, pp. 5-59.

Bollerslev, T.(1986), Generalized Autoregressive Conditional Heteroscedasticity, Journal of Econometrics, 31, pp. 307-327.

Cheung, Y.W., Ng, L.K. (1996), A Causality-in-Variance Test and It's Application to Financial Market Prices, Journal of Econometrics 72, pp. 33-48.

Cheung, Y.W., Ng, L.K. (1990), The Dynamics of S\&P 500 Index and S\&P 500 Futures Intraday Price Volatilities, Review of Futures Markets 9, pp. 458-486.

Coudert V., Coucharde, C., Mignon, V. (2013), On the Impact of Oil Price Volatility On The Real Exchange Rate - Terms of Trade Nexus: Revisiting Commodity Currencies, CEPII Working Paper, No 2013-40 December.

Duygulu, A., A. (1998), Döviz Kuru İstikrarının Ekonomik İstikrar Açısından Değerlendirilmesi, D.E.Ü.İ.i.B.F.Dergisi Cilt:13, Sayı:I, Yıl:1998, ss.107-118.

Doane, P., D., Seward, E., L. (2011), Measuring Skewness: A Forgotten Statistic? Journal of Statistics Education, Volume 19, Number 2(2011).

Domaç, I. ve Mendoza, A. (2002), Is There Room for Forex Interventions Under Inflation Targeting Framework? Evidence from Mexico and Turkey, TCMB Tartışma Tebliğleri No: 0206.
Eraydın, K. (2015), Petrol Fiyatlarındaki Düşüşün Nedenleri ve Etkileri, İş Bankası İktisadi Araştırmalar Bölümü, Ocak 2015.

Enders, W. (2015), Applied Econometric Time Series. Fourth Ed., New York: Wiley Press.

Engle, R., F. (1982),'Autoregressive Conditional Heteroscedasticity with Estimates of the Variance of United Kingdom Inflation", Econometrica, 50, pp. 9871007.

Engle, R.F., Ito, T., Lin, W.L. (1990), Meteor Shower or Heat Waves? Heteroskedastic Intra-Daily Volatility in the Foreign Exchange Market, Econometrica 59, pp. 524-542.

Engle, R.F., Susmel, R. (1993), Common Volatility in International Equity Markets, Journal of Business and Economic Statistics 11, pp. 167-176.

Erez, Y. (1994) "5 Nisan Kararları ve Kur Politikası", Ekonomik Forum, TOBB Yayın Organı, Sayı:6.

Goldberg, P., K., Knetter, M., M. (1997), Goods Prices and Exchange Rates: What Have We Learned?, Journal of Economic Literature, 35(3), pp. 1243-1272.

Granger, C.W.J., Robins, P.P., Engle, R.F. 1(986), Wholesale and Retail Prices: Bivariate Time-Series Modeling with Forecastable Error Variances, In: Belsley, D.A., Kuh, E. (Eds.), Model Reliability, MIT Press, Cambridge, pp. 1-17.

Gujarati, D., N., (2004 ). Basic Econometrics, McGraw Hill,. Intriligator, M.D., Econometric Models, Techniques and Applications, Fourth Edition, Prentice Hall, 2004.

Güloğlu, B. Akman, A. (2007), Türkiye'de Döviz Kuru Oynaklığının SWARCH Yöntemi ile Analizi, Finans Politik \& Ekonomik Yorumlar 2007 Cilt: 44 Sayı: 512.

Hafner, C., M., Herwartz, H. (2008), Testing for Causality in Variance Using Multivariate GARCH Models, Annales d'Économie et de Statistique, No. 89 (Jan. - Mar., 2008), pp. 215-241.

Hafner C., M., Herwartz, H. (2006), A Lagrange Multiplier Test for Casuallity in Variance, Economic Letters, 93 (2006) pp. 137-141. 
Hamao, Y., Masulis, R.W., Ng, V. (1990), Correlations in Price Changes and Volatility Across International Stock Markets, Review of Financial Studies 3, pp. 281307.

Ho, C., McCauley, R., N. (2003), Living with flexible Exchange Rates: Issues and Recent Experience in Inflation Targeting Emerging Market Economies, BIS Working Papers, No: 130.

Hooper, P., and Mann, C., L. (1989). Exchange Rate Pass-through in the 1980s: The Case of U.S. Imports of Manufactures, Brookings Papers on Economic Activity, 1, pp. 297-337.

Hong, Y. (2001), A Test for Volatility Spillover With Application to Exchange Rates, Journal of Econometrics, 103 (2001), pp. 183-224.

Hong, Y. M., White, H. (2001), Asymptotic Theory for Nonparametric Entropy Measures of Serial Dependence, Department of Economics and Department of Statistical Science, Cornell University.

Johansen, S. (1991), Estimation and Hypothesis Testing of Cointegration Vectors in Gaussian Vector Autoregressive Models, Econometrica Vol. 59, No. 6 (Nov., 1991), pp.1551-1580.

Jojansen, S. (1995), A Stastistical Analysis of Cointegration for I(2) Variables," Econometric Theory, Cambridge University Press, vol. 11(01), February, pp. 25-59.

Krugman, P., R., Obstfeld, M. (2000), International Economics: Theory and Policy, Fifth Editon, AddisonWesley, Reading, New York.

King, M., Sentana, E., Wadhwani, S. (1994), Volatility and Links Between National Stock Markets, Econometrica 62, pp. 901-933.

Lebe, F. Akbaş, Y., E. (2015), Ithal Ham Petrol Fiyatları İle Döviz Kurunun Cari Açık Üzerindeki Etkisi: Türkiye İçin Bir Araştırma, Gazi Üniversitesi i.I..B.F. Dergisi, Cilt 17, Sayı 2 (2015).

Lin, W.L., Engle, R.F., Ito, T. (1994) Do Bulls and Bears Move Across Borders? International Transmission of Stock Returns and Volatility, Review of Financial Studies 7, pp. 507-538.

McCarthy, J. (2000), Pass-Through of Exchange Rates and Import Prices to Domestic Inflation in Some Industrialised Economies, Federal Reserve Bank of New York Staff Reports, No: 111.

Mckinnon, R., I.(1984), An International Standard For Monetary Stabilization, Institute For International Economics.
Mennon, J. (1996), The Degree and Determinants of Exchange Rate Pass-Through: Market Structure, NonTariff Barriers and Multinational Corporations, The Economic Journal, 106(435), pp. 434-444.

Nazlioglu, S., Erdem, C., Soytas, U. (2013), Volatility Spillover Between Oil And Agricultural Commodity Markets, Energy Economics 36, pp. 658-665.

Narayan, P., K., Smyth, R., (2006), Dead man walking: an empirical reassessment of the deterrent effect of capital punishment using the bounds testing approach to cointegration, Applied Economics, Taylor \& Francis Journals, vol. 38(17), pp. 1975-1989.

Neal, C., B., (1996), Does Central Bank Intervention Stabilize Foreign Exchange Rates?, Federal Reserve Bank of Kansas City, Economic Review, First Quarter, 81 (1).

Ogundipe, M., O., Ojeaga, P., Ogundipe A., A. (2014), Oil Price and Exchange Rate Volatility in Nigeria, IOSR Journal of Economics and Finance (IOSR-JEF) e-ISSN: 2321-5933, p-ISSN: 2321-5925.Volume 5, Issue 4. (Sep.-Oct. 2014), pp. 01-09.

Ojebiyi, A., Wilson, D., O. (2011), Exchange Rate Volatility: An Analysis Of The Relationship Between The Nigerian Naira, Oil Prices, And Us Dollar, Gothland University, Master Thesis in Business Administration 15 ECTS, Spring Semester 2011.

Oksay, S.,(2001), Döviz Kuru ve Ödemeler Bilançosu Politikaları: Türkiye (1923-2000), Beta Basım, İstanbul.

Özçam, M. (2004), Döviz Kuru Politikaları ve Türkiye'de Döviz Kuru Oynaklığının Etkileşimleri, Sermaye Piyasası Kurulu Araştırma Raporları 27.02.2004.

Özdamar, G. (2015), Türkiye Ekonomisinde Döviz Kuru Geçiş Etkisi: Ardl-Sınır Testi Yaklaşımı Bulguları, niz Üniversitesi i.I..B.F dergisi (32) 2015, ss. 66-97.

Öztürk, K. (2010), Döviz Kuru Oynaklığı Ve Döviz Kuru Oynaklığının Faiz Oranı Oynaklığı ile Olan illişkisi Türkiye Örneği, Uzmanlık Yeyerlilik Tezi, Türkiye Cumhuriyet Merkez Bankası Piyasalar Genel Müdürlüğü, Ankara, Nisan 2010.

Öztürk, E. (1992), Türkiye' de Son Dönemde Para Politikası Tartışmaları", TCMB Araştırma ve Eğitim Genel Müdürlüğü, Tartışma Tebliğleri, No:9206.

Özçam, M. (2004), Döviz Kuru Politikaları ve Türkiye'de Döviz Kuru Oynaklığının Etkileşimleri, Uzmanlık Yeterlilik Tezi, Sermaye Piyasası Kurulu Araştırma Raporu.

Philips, B., Ouliaris, S. (1990), Asymptotic Properties of Residual Based Tests for Cointegration, Econometrica, Vol. 58, No. 1 (Jan., 1990), pp. 165-193 
Polat, F., Y. (2015), Döviz Kurları, Ülke Ekonomisi Iç̧in Önemi Ve Kur Savaşları, Hitit Üniversitesi Sosyal Bilimler Enstitüsü İktisat Anabilim Dalı Yüksek Lisan Tezi, Çorum 2015.

Press, H., W., Teukolsky, S., A., Vettreling, W., T., Flannery, B., P. (1992), Numerical Recipes in C: The Art of Scientific Computing, Cambridge University Press, Second Edition, Printed in the U.S.A.

Pesaran, H., M., Shin, Y., Smith, R., J. (2001), Bounds Testing Approaches To The Analysis Of Level Relationships, Journal Of Applied Econometrics, J. Appl. Econ. 16: 289-326 (2001) DOI: 10.1002/jae.616.

Pesaran, H., M., Shin, Y. (1995), An autoregressive distributed lag modeling approach to cointegration analysis (DAE Working paper no. 9514). Department of Economics, University of Cambridge.

Saray, M.O. (2011), Doğrudan Yabancı Yatırımlarİstihdam Illişkisi: Türkiye Örneği, Maliye Dergisi, Sayı: 161, Temmuz-Aralık 2011.

Shafi, K., Hua, L., Idrees, Z. (2015), Exchange Rate Volatility And Oil Prices Shocks And Its Impact On Economic Sustainability, Management Science Letters 5 (2015) pp. 59-64.

Shrestha, M., B., Chowdhury, K. (2005), ARDLModelling Approach to Testing the Financial Liberalisation,
Working Paper 05-15, Department of Economics, University of Wollongong.

Seyidoğlu, H. (2009), Uluslararası Iktisat: Teori, Politika ve Uygulama, 17. Baskı, Güzem Can Yayıncılık, İstanbul.

TCMB (2015), Türkiye Cumhuriyeti Merkez Bankası Enflasyon Raporu, 2015 IV.

Türkcan, E. (1982) IMF İstikrar Politikaları ve Türkiye, Editör: Cevdet Erdost, Ankara, Savaş Yayınları

Türkel, J. (2014), Sözlü Döviz Müdahalelerinin Döviz Kuru Üzerindeki Etkisi: Türkiye Örneği, Uzmanlık Yeterlilik Tezi, Türkiye Cumhuriyet Merkez Bankası İletişim ve Dış ilişkiler Genel Müdürlüğü Ankara, Ekim 2014.

Ünal, S., Ö. (2009), Döviz Kuru Oynaklığının Öngörülmesi ve Risk Yönetimi Türkiye Örneği Uzmanlık Yeterlilik Tezi, Türkiye Cumhuriyet Merkez Bankası Piyasalar Genel Müdürlüğü Ankara, Haziran 2009.

Wooldridge, J.M. (2002). Introductory Econometrics A Modern Approach, 2nd. edition, 2002, Thomson Learning.

Vogelvang, B. (2005), Econometrics; Theaory and Application with E-Views, Prentice Hall, Pearson Education Limited, 2005. 